\title{
Masculinization in male rats is inhibited by neonatal injections of dihydrotestosterone
}

\author{
P. van der Schoot, Paula D. M. van der Vaart and J. T. M. Vreeburg \\ Department of Endocrinology, Growth and Reproduction, Medical Faculty, Erasmus University, \\ Rotterdam, The Netherlands
}

Masculinization of the brain of the neonatal male rat is known to be dependent on testicular androgen, and leads to an absence of cyclicity in ovarian transplants in adulthood and inability to show lordosis in response to appropriate stimuli. While both brain and pituitary may be involved in neonatal testicular activation (Kawashima, 1964; Yaginuma, Matsuda, Murasawa, Kobayashi \& Kobayashi, 1969; Goldman \& Mahesh, 1970; Goldman, Quadagno, Shryne \& Gorski, 1972; Arai \& Serisawa, 1973; Arai, 1974), blood concentrations of gonadotrophins in male neonates are low or undetectable (Goldman, Grazia, Kamberi \& Porter, 1971; Döhler \& Wuttke, 1974). Dihydrotestosterone propionate (DHTP) is known to stimulate differentiation and growth of male accessory sex organs (Schultz \& Wilson, 1974), and inhibit gonadotrophin secretion (Korenbrot, Paup \& Gorski, 1975) but does not masculinize the brain (Luttge \& Whalen, 1970; McDonald \& Doughty, 1972). We therefore used this substance to determine whether gonadotrophins are required for the testicular activation which brings about masculinization of the neonatal male rat brain.

Locally bred $(\mathrm{R} \times \mathrm{U}) \mathrm{F}_{1}$ hybrid rats derived from two inbred Wistar substrains were used. In these rats masculinization of the brain in males occurs on the first day of life with respect to cyclicity in ovarian transplants (Day 1, 100\%, N=30; Day 2, 23\%, N=17; Day 5, 0\%, N=16). However, masculinization with respect to lordosis with intact male rats in response to $0.05 \mathrm{mg}$ oestradiol benzoate $+1 \mathrm{mg}$ progesterone 48 and $4 \mathrm{hr}$ respectively before testing has not occurred by Day 5 (lordosis quotient $95 \pm 3$ (S.E.M.), $\mathrm{N}=6$, on Day $1 ; 95 \pm 4, \mathrm{~N}=12$, on Day 5).

Intact male and female rats were injected within $4 \mathrm{hr}$ after birth (= Day 1 of life) with $1 \mathrm{mg}$ DHTP dissolved in $0.05 \mathrm{ml}$ arachis oil or with oil only. The injections were repeated on Days 3, 5, 10 and 15. Testosterone concentrations were determined as described by Verjans, Cooke, De Jong, De Jong \& Van der Molen (1973), except that silica gel plates were used to separate completely testosterone and dihydrotestosterone. Serum concentrations of FSH and LH were determined by radioimmunoassays (Welschen et al., 1975) and expressed in ng NIAMDD-rat-FSH-RP1/ml and ng NIAMDD-rat-LH-RP1/ml, respectively. Neonatal injections of DHTP interfered with theoccurrence of cyclic ovarian activity in $3 / 11$ female rats but lordosis behaviour with intact males seemed unchanged.

The effects of DHTP injections in male rats are summarized in Table 1. There was a marked reduction in adult testicular weight, a decrease in testicular testosterone concentrations on Day 5 and almost complete suppression of gonadotrophin secretion after castration on Day 1. Cyclicity in ovarian transplants was observed in two rats but lordosis behaviour occurred consistently.

In a separate experiment the possibility was examined that DHTP could act competitively with testosterone and thus inhibit masculinization. Neonatal female rats were therefore injected with testosterone propionate combined with oil or DHTP in oil. As shown in Table 2 DHTP did not prevent testosterone propionate-induced blockade of ovulation and decrease of the lordosis quotient.

The present experiments demonstrate that masculinization of the neonatal male rat brain can be inhibited by neonatal injections of dihydrotestosterone propionate. The inhibition of increased gonadotrophin secretion after castration and the reduction of testicular testosterone concentrations in intact rats after administration of DHTP suggest that peripheral concentrations of gonadotrophin and testosterone in intact DHTP-treated male rats are very low. While, therefore, inhibition of masculinization by DHTP may be attributed to suppression of the secretion of gonadotrophins (and, 
Table 1. The effect of repeated injections of dihydrotestosterone propionate during the neonatal period in male rats (results given as means $\pm S E M$; no. in parentheses)

\begin{tabular}{|c|c|c|c|c|c|c|}
\hline \multirow[b]{2}{*}{ Treatment } & \multirow{2}{*}{$\begin{array}{c}\text { Testicular } \\
\text { wt (mg) } \\
\text { (Days } 80-270)\end{array}$} & \multirow{2}{*}{$\begin{array}{l}\text { Testicular } \\
\text { testosterone } \\
\text { conc.* } \\
\text { (ng/g testis) }\end{array}$} & \multicolumn{2}{|c|}{ Serum conc. $\dagger$} & \multirow{2}{*}{$\begin{array}{l}\text { Cyclicity in } \\
\text { ovarian } \\
\text { transplants }\end{array}$} & \multirow{2}{*}{$\begin{array}{c}\text { Lordosis } \\
\text { behaviour\& } \\
\text { (quotient) }\end{array}$} \\
\hline & & & LH & FSH & & \\
\hline Oil & $\begin{array}{c}1250 \pm 35 \\
(10)\end{array}$ & $179 \pm 75$ & $\begin{array}{c}240 \pm 50 \\
(8)\end{array}$ & $2350 \pm 130$ & $0 / 18$ & $\begin{array}{c}0 / 6 \\
(0-4)\end{array}$ \\
\hline DHTP & $\begin{array}{c}830 \pm 35 \\
(11)\end{array}$ & $25 \pm 12$ & $\begin{array}{l}<20 \\
(9)\end{array}$ & $\begin{array}{l}<110 \\
(8)\end{array}$ & $2 / 9$ & $\begin{array}{r}13 / 13 \\
(72-100)\end{array}$ \\
\hline Significance & $P<0.001$ & $P<0.05$ & $P<0.001$ & $P<0.001$ & - & $P<0.001$ \\
\hline
\end{tabular}

* Exp. design: injection of $1 \mathrm{mg}$ DHTP or oil on Days 1 and 3; autopsy on Day 5.

+ Exp. design: castration on Day 1; injection of $1 \mathrm{mg}$ DHTP or oil on Days 1, 3, 5, 7; autospy on Day 9.

$\ddagger$ Ovarian and vaginal tissue grafted at the time of castration at 30-50 days of age; autopsy 30 days later.

$\S$ Oestradiol benzoate $(0.05 \mathrm{mg})+$ progesterone $(1 \mathrm{mg})$ given 48 and $4 \mathrm{hr}$ respectively before testing with intact male rats.

Table 2. The absence of a protective action of dihydrotestosterone propionate (1 mg on Days 4 and $6,0.6 \mathrm{mg}$ on Day 5) on the effects of an injection of $0.25 \mathrm{mg}$ testosterone propionate (on Day 5) in female rats

\begin{tabular}{lccccc}
\hline \multicolumn{1}{c}{ Treatment } & $\begin{array}{c}\text { No. of } \\
\text { rats }\end{array}$ & $\begin{array}{c}\text { Oestrous cycles } \\
\text { Days 40-60 and } \\
\text { CL on Day 60 }\end{array}$ & $\begin{array}{c}\text { Lordosis behaviour } \\
\text { when ovaries in situ } \\
\text { contained follicles } \\
\text { only }\end{array}$ & $\begin{array}{c}\text { Lordosis } \\
\text { Ovulation } \\
\text { induction* }\end{array}$ & $\begin{array}{c}\text { behaviour } \\
\text { (quotient) }\end{array}$ \\
\hline DHTP + testosterone & 12 & $1 / 12$ & $1 / 6$ & $0 / 5$ & $\begin{array}{c}5 / 9 \\
(43 \pm 5) \\
9 / 9\end{array}$ \\
Oil + testosterone & 11 & $1 / 11$ & $1 / 5$ & $0 / 5$ & $(53 \pm 9)$ \\
\hline
\end{tabular}

* Examination $24 \mathrm{hr}$ after a single injection of $5 \mathrm{mg}$ progesterone.

$\dagger$ Oestradiol benzoate $(0.05 \mathrm{mg})+$ progesterone $(1 \mathrm{mg})$ given 48 and $4 \mathrm{hr}$ respectively before testing with intact male rats.

secondarily, of testosterone), it cannot be due to direct inhibition of the action of testosterone on the brain. It is clear that circulating gonadotrophins, although low (Goldman et al., 1971; Döhler \& Wuttke, 1974), in neonatal male rats are essential for masculinization of the brain.

There may be several reasons why complete inhibition was not obtained in the present study. Firstly DHTP itself may have a weak masculinizing effect on the brain (Gerall, McMurray \& Farrell, 1975) as suggested also by the finding that it interfered with the development of cyclic ovarian activity in some female rats. Secondly, there must be a latency between the time of injection of DHTP and suppression of testicular testosterone production. Production is highest on the 1st day of life (Resko, Feder \& Goy, 1968; Döhler \& Wuttke, 1974; Warren, Haltmeyer \& Eik-Nes, 1975) and the delay might be sufficient to produce masculinization to a degree comparable to that found in male rats castrated on the 2 nd day of life. Thirdly, the possibility should be considered that testicular testosterone secretion in the perinatal period is independent of stimulation by gonadotrophins (Price \& Ortiz, 1965; Noumura, Weisz \& Lloyd, 1966; Wilson \& Siiteri, 1973; Warren et al., 1975). It would then follow from the present data that the hypothalamo-hypophysial system gains control over testicular activity during the 1 st or 2 nd day of life.

This study was supported in part by the Foundation of Medical Research (FUNGO) which is subsidized by the Netherlands Organization for the Advancement of Pure Research (Z.W.O.). The critical comments on the manuscript of Dr J. J. van der Werff ten Bosch are highly appreciated. 


\section{References}

ARAI, Y. (1974) Advancement of masculine differentiation of the brain by synthetic $\mathrm{LH}$-releasing hormone (LH-RH) in the male rat. Endocr. jap. 21, 121-123.

ARAI, Y. \& SERISAWA, K. (1973) Effect of gonadotropins on neonatal testicular activity and sexual differentiation of the brain of the rat. Proc. Soc. exp. Biol. Med. $143,656-660$.

Döhler, K.D. \& Wuttke, W. (1974) Serum LH, FSH, prolactin and progesterone from birth to puberty in female and male rats. Endocrinology 94, 10031008.

Gerall, A.A., McMurray, M.M. \& Farrell, A. (1975) Suppression of the development of female hamster behaviour by implants of testosterone and non-aromatizable androgens administered neonatally. J. Endocr. 67, 439-445.

Goldman, B.D. \& MaHESH, V.B. (1970) Induction of infertility in male rats by treatment with gonadotropin antiserum during neonatal life. Biol. Reprod. 2, 444-451.

Goldman, B.D., Grazia, Y.R., Kamberi, I.A. \& Porrer, J.C. (1971) Serum gonadotropin concentrations in intact and castrated neonatal rats. Endocrinology 88, 771-776.

Goldman, B.D., Quadagno, D.M., Shryne, J. \& Gorski, R.A. (1972) Modification of phallus development and sexual behavior in rats treated with gonadotropin antiserum neonatally. Endocrinology 90, 1025-1031.

KAWASHIMA S. (1964) Inhibitory action of reserpine on the development of the male pattern of gonadotropin secretion in the rat. Annotnes zool. jap. 37, 79-85.

Korenbrot, C.C., PAUP, D.C. \& GorSKi, R.A. (1975) Effects of testosterone propionate or dihydrotestosterone propionate on plasma FSH and LH levels in neonatal rats and on sexual differentiation of the brain. Endocrinology 97, 709-717.

Luttge, W.G. \& Whalen, R.E. (1970) Dihydrotestosterone, androstenedione, testosterone: comparative effectiveness in masculinizing and de- feminizing reproductive systems in male and female rats. Horm. \& Behav. 1, 265-281.

McDonald, P.G. \& Doughty, C. (1972) Comparison of the effect of neonatal administration of testosterone and dihydrotestosterone in the female rat. J. Reprod. Fert. 30, 55-62.

Noumura, T., Weisz, J. \& Lloxd, C.W. (1966) In vitro conversion of $7-{ }^{3} \mathrm{H}$-progesterone to androgens by the rat testis during the second half of fetal life. Endocrinology 78, 245-253.

Price, D. \& ORTIz, E. (1965) The role of fetal androgen in sex differentiation in mammals. In Organogenesis, pp. 629-652, Eds R.L. DeHaan \& H. Ursprung. Holt Rinehart \& Winston Inc., New York.

ResKo, J.A., Feder, H.H. \& GoY, R.W. (1968) Androgen concentrations in plasma and testis of developing rats. $J$. Endocr. 40, 485-491.

SchulTz, F.M. \& Wilson, J.D. (1974) Virilization of the Wolffian duct in rat fetus by various androgens. Endocrinology 94, 979-986.

Verjans, H.L., Cooke, B.A., De Jong, F.H., De Jong, C.M.M. \& VAN DER MOLEN, H.J. (1973) Evaluation of a radioimmunoassay for testosterone estimation. J. Steriod Biochem. 4, 665-676.

Warren, D.W., HaltmeYer, G.C. \& Eik-Nes, K.B. (1975) The effect of gonadotrophins on the fetal and neonatal rat testis. Endocrinology 96, 1226-1229.

Welschen, R., Osman, P., Dullaart, J., De Greef, W.J., UILENBROEK, J.TH.J. \& DE JONG, F.H. (1975) Levels of follicle-stimulating hormone, luteinizing hormone, oestradiol-17 $\beta$ and progesterone, and follicular growth in the pseudopregnant rat. $J$. Endocr. 64, 37-47.

WiLson, J.D. \& SiITERI, P.K. (1973) Developmental pattern of testosterone synthesis in the fetal gonad of the rabbit. Endocrinology 92, 1182-1191.

Yaginuma, T., Matsuda, A., Murasawa, Y., Kobayashi, T. \& Kobayashi, T. (1969) Presence of hypothalamo-pituitary testicular axis in the early postnatal period. Endocr. jap. 16, 5-10.

Received 14 April 1976 